\title{
The Development of the Turkish Craving for Internet Gaming Scale (CIGS): A Validation Study
}

\author{
Mustafa Savci ${ }^{1} \cdot$ Mark D. Griffiths $^{2}$ (iD
}

Published online: 2 August 2019

(C) The Author(s) 2019

\begin{abstract}
As the use of digital technology has increased, abuse and addiction to technology have been identified among a minority of users. In the mid-1990s, the concept of internet addiction was first used. Today, almost every digital technology use has been claimed to have a minority of disordered users. One key aspect of addictive substance behaviors is craving. Craving is also an important component of behavioral addictions including digital technology disorders such as Internet Gaming Disorder. The aim of the present study was to develop the Turkish version of the Craving for Internet Gaming Scale (CIGS) via an adaptation of the Penn Alcohol Craving Scale (PACS). The present study comprised 368 adolescents from four different samples. The measures used included the Craving for Internet Gaming Scale, Digital Game Addiction Scale, and Brief Self-Control Scale. The structural validity of CIGS was investigated with Exploratory Factor Analysis (EFA), Confirmatory Factor Analysis (CFA), and criterion validity. The reliability of CIGS was evaluated using Cronbach $\alpha$ internal consistency reliability coefficient and corrected item total correlation coefficients. As a result of EFA, it was found that the five-item CIGS had a single-factor structure. The unidimensional CIGS obtained as a result of EFA was tested with CFA. As a result of CFA, the unidimensional structure of CIGS was confirmed in two different samples. Criterion validity of CIGS was assessed via digital gaming addiction, self-discipline, impulsiveness, daily internet gaming duration, and internet gaming history. As a result of criterion analysis, CIGS was associated with these variables in the expected direction. Finally, according to reliability analysis, the CIGS was found to be a reliable scale. When validity and reliability analysis of the CIGS are considered as a whole, it is concluded that the CIGS is a valid and reliable scale that assesses craving for internet gaming.
\end{abstract}

Keywords Online gaming · Internet gaming disorder · Craving · Internet gaming craving · Online gaming addiction

Mark D. Griffiths

mark.griffiths@ntu.ac.uk

Extended author information available on the last page of the article 
The latest (fifth) edition of the Diagnostic and Statistical Manual of Mental Disorders (DSM5) describes craving as "a strong desire/urge" to use a substance (American Psychiatric Association [APA] 2013). Similarly, the tenth edition of the International Classification of Diseases (ICD-10) defines craving as "a strong desire or sense of compulsion" to use a particular substance (WHO 1993). The concept of craving has traditionally been conceptualized for alcohol and substance addiction as described in both the DSM-5 and ICD-10 (APA 2013; WHO 1993). Craving is intensely felt by individuals in the process of giving up a substance (Kavanagh et al. 2013). However, in recent years, the concept of craving has been used in the evaluation of behavioral addictions (Grant et al. 2010; Holden 2001; Sauvaget et al. 2015). Indeed, behavioral addictions and substance addictions have been shown to be similar in many respects (Griffiths 2005). In behavioral addictions, an urge or craving can occur before addictive behavior develops (Grant et al. 2010). In addition, craving can be implicated in the development, continuity, and relapse of addictive behavior, and can lead to loss of control over that behavior or substance within an individual's behavior (Sauvaget et al. 2015). According to scholars (e.g., Grant et al. 2010; Griffiths 1996a), behavioral addictions can be similar to substance addictions in many ways including natural history, phenomenology, tolerance, comorbidity, overlapping genetic contribution, neurobiological mechanisms, and response to treatment. In the DSM-5, behavioral addictions refer to behavioral disorders that share some features related to substance abuse but are not associated with any substance (APA 2013).

In the literature, addictions to gambling, sex, pornography, exercise, shopping, food, and gaming have been conceptualized as behavioral addictions (Andreassen et al. 2015; APA 2013; Freeman 2008; Gearhardt et al. 2009; Griffiths 2005; Moreyra et al. 2002; Terry et al. 2004; Voros 2009). In recent years, increased Internet use has led to a minority of individuals experiencing problems such as internet gaming addiction and social media addiction (Kuss et al. 2014; Kuss and Griffiths 2017). In the DSM-5, Internet Gaming Disorder (IGD) is conceptualized as a tentative disorder that requires further research. In the DSM-5, IGD is diagnosed if five or more of the symptoms below are endorsed over a 12-month period (APA 2013).

$\begin{array}{ll}\text { Preoccupation } & \begin{array}{l}\text { 1. Preoccupation with internet games. (The individual thinks about previous gaming activity } \\ \text { or anticipates playing the next game; internet gaming becomes the dominant activity in } \\ \text { daily life). Note: This disorder is distinct from internet gambling disorder, which is } \\ \text { included under gambling disorder. }\end{array} \\ \text { Withdrawal } & \begin{array}{l}\text { 2. Withdrawal symptoms when internet gaming is taken away. (These symptoms are typically } \\ \text { described as irritability, anxiety, or sadness, but there are no physical signs of } \\ \text { pharmacological withdrawal.) }\end{array} \\ \text { Tolerance } & \begin{array}{l}\text { 3. Tolerance involving the need to spend increasing amounts of time engaged in internet } \\ \text { games. }\end{array} \\ \text { Persistence } & \begin{array}{l}\text { 4. Unsuccessful attempts to control the participation in internet games. } \\ \text { Displacement }\end{array} \\ \text { 5. Loss of interests in previous hobbies and entertainment as a result of, and with the } \\ \text { exception of, internet games. } \\ \text { Awareness } & \begin{array}{l}\text { 6. Continued excessive use of internet games despite knowledge of psychosocial problems. } \\ \text { Deception }\end{array} \\ \begin{array}{l}\text { 7. Has deceived family members, therapists, or others regarding the amount of internet } \\ \text { gaming. }\end{array} \\ \text { Escape } & \begin{array}{l}\text { 8. Use of internet games to escape or relieve a negative mood (e.g., feelings of helplessness, } \\ \text { guilt, and anxiety). }\end{array} \\ \text { Missed } & \begin{array}{l}\text { 9. Has jeopardized or lost a significant relationship, job, or educational or career opportunity } \\ \text { because of participation in internet games. }\end{array} \\ \text { opportunities } & \end{array}$

Unlike the DSM-5, in ICD-11, internet gaming disorder is considered a disorder (under gaming disorder). According to the World Health Organization (WHO 2016), gaming disorder is characterized by a pattern of persistent or recurrent gaming behavior ("digital gaming" or 
"video-gaming"), which may be online (i.e., over the Internet) or offline, manifested by:

$\begin{array}{ll}\begin{array}{l}\text { Loss of } \\ \text { control } \\ \text { Displacement }\end{array} & \begin{array}{l}\text { 1. Impaired control over gaming } \\ \text { interests and daily activities }\end{array} \\ \text { Escape } & \begin{array}{l}\text { 3. Continuation or escalation of gaming despite the occurrence of negative consequences } \\ \hline\end{array}\end{array}$

These symptoms in many areas impede the functioning of the individual (personal, family, social, educational, occupational, or other important areas). The pattern of gaming behavior may be continuous or episodic and recurrent (WHO 2016). Research has shown that IGD is related to specific personality traits such as neuroticism (Gervasi et al. 2017; González-Bueso et al. 2018), psychopathology (Bargeron and Hormes 2017; González-Bueso et al. 2018; King and Delfabbro 2016), poor psychological wellbeing (Bargeron and Hormes 2017; Cheng et al. 2018; Sarda et al. 2016), lower academic performance (Hawi et al. 2018; Sahin et al. 2014), lower social connectedness (Sarda et al. 2016; Savci and Aysan 2017), impulsivity (Bargeron and Hormes 2017; Kim et al. 2017; Ryu et al. 2018), poor sleep quality (Hawi et al. 2018; Lam 2014), and poor interpersonal relationships (APA 2013; Ryu et al. 2018). Given these findings, it can be said that IGD has a broad etiological spectrum. In addition, it is predicted that IGD will become a significant health problem for a minority of individuals in the coming years. Research has also demonstrated that adolescents and emerging adults are a risk group for developing IGD, particularly among males (King and Delfabbro 2016; Kuss and Griffiths 2012). According to King and Delfabbro (2014), adolescents with IGD have four main characteristics that make adolescents vulnerable to internet gaming disorder: (i) beliefs about game reward value and tangibility, (ii) maladaptive and inflexible rules about gaming behavior, (iii) over-reliance on gaming to meet self-esteem needs, and (iv) gaming as a method of gaining social acceptance.

Numerous studies have been carried out on the prevalence of IGD. However, the use of different measuring tools comprising differing criteria has resulted in different results even in the same countries and cultures. The DSM-5 emphasizes that IGD is more common in Asian countries and among male adolescents (aged 12-20 years). Feng et al. (2017) examined 27 studies on normal population between 1998 and 2016 and found the mean average prevalence rate to be $4.7 \%$. In a different study, the prevalence of IGD was found to be between 10 and $15 \%$ in the Far East countries, 1-10\% in Western countries, and 1-9\% in South American and African countries (Saunders et al. 2017). There are a limited number of studies concerning IGD in Turkey (the country of the present study). In a study by Turkish Green Crescent (2017), the prevalence of problematic digital gaming play among 6116 Turkish adolescents (aged 1219 years) was reported as being $8.5 \%$ (Aricak et al. 2018). Some scholars claim that the prevalence of IGD is increasing worldwide among both school-aged students and among representative samples of the general population (Feng et al. 2017).

IGD appears to be a problem threatening adolescent health in many countries worldwide (Feng et al. 2017). This makes it necessary to recognize and assess such a problem with wellvalidated measurement tools for IGD. Indeed, there are no well-researched subtypes of IGD. Gaming disorder often involves specific online games such as role-playing games and battle arena games, but can also involve offline games as demonstrated by all the studies published in the 1980s and 1990s (Griffiths et al. 2012). It is likely that preferred games will vary over time as new games are developed and popularized. Further research on the subtypes of IGD is needed (APA 2013). While gaming addiction is similar to substance addiction in many respects, the concept of craving is arguably noteworthy. In recent years, research into craving for online gaming has been carried out. Such research has reported that game addicts 
experienced craving for online gaming (Dong et al. 2017; King et al. 2016; Kim et al. 2018; Shin et al. 2018; Zhang et al. 2016). These studies also show that craving occurs in IGD as it does in substance addiction. When the DSM-5 definition of craving is taken into consideration, craving for online gaming is also defined as a strong desire/urge to engage in gaming online (APA 2013). When the ICD-10 definition of craving is taken into consideration, it is defined as a strong desire or sense of compulsion to engage in gaming online (WHO 1993).

Although there are many scales that assess IGD (King et al. 2013; Pontes 2016), no scale exists that assesses craving for internet gaming. However, different measurement methods have been used to assess craving for online gaming. The most commonly used methods are qualitative self-report techniques, multimodal biosignals, functional magnetic resonance imaging (fMRI), visual analogue scales, and plasma levels of leptin (Dong et al. 2017; King et al. 2016; Kim et al. 2018; Shin et al. 2018; Zhang et al. 2016). The creation of a self-rating scale for gaming craving may help to stimulate studies in the area. There is also a need for valid and reliable scales to facilitate cross-cultural studies. Consequently, the present study adapted a widely used craving scale rather than develop a completely new scale from scratch (i.e., the Penn Alcohol Craving Scale) which has been adapted in many cultures (e.g., Chodkiewicz et al. 2018; Evren et al. 2008; Kim et al. 2008; Pérez Gálvez et al. 2016). Therefore, the primary aim of the study was to adapt and validate a Turkish version of the PACS to assess craving among gamers.

\section{Methods}

\section{Participants}

The present study comprised 368 adolescents (172 females and 196 males) from four different samples in including a pilot study comprising 30 students (18 girls and 12 boys). The structural reliability and validity were performed on a convenience sample of 338 students from three different samples. Structural validity was performed using exploratory factor analysis (EFA), confirmatory factor analysis (CFA), and criterion validity. EFA was performed on 102 adolescents, CFA was performed on 103 adolescents, and criterion validity on 133 adolescents. Demographic information of the four study groups is presented in Table 1.

Table 1 Demographic information of the study groups

\begin{tabular}{|c|c|c|c|c|c|c|c|c|c|}
\hline & & \multicolumn{2}{|c|}{ EFA Sample } & \multicolumn{2}{|c|}{ CFA Sample } & \multicolumn{2}{|c|}{ Criterion validity sample } & \multicolumn{2}{|c|}{$\begin{array}{l}\text { Pilot study } \\
\text { sample }\end{array}$} \\
\hline & & $N$ & $\%$ & $N$ & $\%$ & $N$ & $\%$ & $N$ & $\%$ \\
\hline \multirow[t]{2}{*}{ Sex } & Girl & 49 & 48 & 35 & 34 & 70 & 52.6 & 18 & 60 \\
\hline & Boy & 53 & 52 & 68 & 66 & 63 & 47.4 & 12 & 40 \\
\hline \multicolumn{2}{|c|}{$\begin{array}{l}\text { Daily internet gaming } \\
\text { duration }\end{array}$} & \multicolumn{2}{|c|}{$\begin{array}{l}.16-10 \mathrm{~h}, \\
\bar{X}=2.58 \mathrm{~h}\end{array}$} & \multicolumn{2}{|c|}{$\begin{array}{l}.16-12 \mathrm{~h}, \\
\bar{X}=2.33\end{array}$} & \multicolumn{4}{|c|}{$.25-11 \mathrm{~h}$} \\
\hline \multicolumn{2}{|c|}{ Internet gaming history } & \multicolumn{2}{|c|}{$\begin{array}{l}1-12 \text { years, } \\
\bar{X}=4.6 \text { years }\end{array}$} & \multicolumn{2}{|c|}{$\begin{array}{l}1-15 \text { years, } \\
\bar{X}=4.73\end{array}$} & \multicolumn{2}{|c|}{$\begin{array}{l}1-12 \text { years, } \\
\bar{X}=4.49\end{array}$} & & \\
\hline \multicolumn{2}{|l|}{ Age } & \multicolumn{2}{|c|}{$\begin{array}{l}14-20 \text { years, } \\
\bar{X}=16.59 \pm .88\end{array}$} & \multicolumn{2}{|c|}{$\begin{array}{l}14-18 \text { years, } \\
\bar{X}=15.94 \pm .96\end{array}$} & \multicolumn{2}{|c|}{$\begin{array}{l}14-18 \text { years, } \\
\bar{X}=16.53 \pm 1.33\end{array}$} & \multicolumn{2}{|c|}{$14-18$} \\
\hline \multicolumn{2}{|c|}{ Total } & \multicolumn{2}{|c|}{102} & \multicolumn{2}{|c|}{103} & \multicolumn{2}{|c|}{133} & \multicolumn{2}{|l|}{30} \\
\hline
\end{tabular}




\section{Materials}

Craving for Internet Gaming Scale In the present study, the PACS developed by Flannery et al. (1999) was adapted to develop the Craving for Internet Gaming Scale (CIGS). The fiveitem PACS is a self-report measure that asks individuals to rate the intensity, frequency, and duration of their craving, and ability to resist acting on their craving for a stated period of time. The PACS also asks individuals to average their craving for the preceding week. The PACS is a unidimensional scale comprising five items and produces a score ranging from 0 to 6 . High scores on the scale indicate high levels of alcohol craving. The Cronbach's alpha internal consistency reliability coefficient for PACS was previously calculated to be .92 . The criterion validity of the original PACS was assessed using the Obsessive-Compulsive Drinking Scale (Modell et al. 1992), Alcohol Urge Questionnaire (Bohn et al. 1995), Addiction Severity Index (McLellan et al. 1980), and Drinker's Inventory of Consequences (Miller et al. 1995). The predictive validity of the original scale was based on relapse. Consequently, the PACS is a valid and reliable scale to assess alcohol craving. The PACS has also been translated into Turkish by Evren et al. (2008) for alcohol-addicted men. In the present study, PACS was adapted to Turkish as CIGS by replacing the word "alcohol" with the words "internet gaming." Further details of the adaptation, validity, and reliability process of the CIGS is given in the following sections.

Digital Game Addiction Scale The Digital Game Addiction Scale (DGAS-7) was developed by Lemmens et al. (2009) and adapted into Turkish by Yalcın-Irmak and Erdoğan (2015). It utilizes a Likert-type scale comprising seven items and a single dimension. EFA has demonstrated that the DGAS-7 had a unidimensional structure explaining $56.96 \%$ of the total variance. This unidimensional structure was then tested with CFA. As a result of the CFA, the DGAS model had acceptable compliance index values $\left(\chi^{2}=14.22, p=.37, \mathrm{df}=14\right.$, $\mathrm{RMSEA}=.012, \mathrm{AGFI}=.92, \mathrm{CFI}=.99, \mathrm{GFI}=.96$, and $\mathrm{SRMR}=.06)$. Factor loading values of the DGAS-7 in the present study ranged from .77 to .52 (all acronyms are described in Table 2). In a previous study, the Cronbach's alpha internal consistency coefficient of DGAS-7 was found to be .72 and the test-retest correlation was found to be .80 . There are no items rated in reverse and the high scores indicate that the risk of digital gaming addiction increases (Yalcın-Irmak and Erdoğan 2015). In the present study, Cronbach's alpha coefficient was .86.

Brief Self-Control Scale The Brief Self-Control Scale (BSCS) was developed by Tangney et al. (2004) and adapted into Turkish by Nebioglu et al. (2012). It comprises nine items across two dimensions (impulsiveness and self-discipline) and utilizes a 5-point Likert-type scale. As a result of the CFA, the BSCS was found to have perfect fit indices $\left(\chi^{2} / \mathrm{df}=1.98, \mathrm{CFI}=.98\right.$, $\mathrm{GFI}=.99$, and RMSEA $=.043)$. The criterion validity of the BSCS was assessed by social intelligence, emotion management skills, and impulsivity. Cronbach's $\alpha$ internal consistency reliability coefficients of the BSCS ranged between .81 and .87 in a previous study (Nebioglu et al. 2012). In the present study, the Cronbach's alpha coefficient was .67.

\section{Procedure}

The adaptation of the PACS to the Turkish CIGS started with the approval of the Ethics Committee and with permission to collect data. Following this, the adapted PACS was 
Table 2 Goodness of fit indices and acceptable limits

\begin{tabular}{ll}
\hline Indices & Acceptable limits \\
\hline$\chi^{2 / d f}$ & $\leq 5$ acceptable fit, $\leq 3$ perfect fit \\
RMSEA & $\leq 0.10$ weak fit, $\leq 0.08$ good fit, $\leq 0.05$ perfect fit \\
GFI & $.85-.89$ acceptable fit, $\geq .90$ good fit \\
AGFI & $.85-.89$ acceptable fit, $\geq .90$ good fit \\
CFI & $\geq .90$ acceptable fit, $\geq .95$ good fit, $\geq .97$ perfect fit \\
IFI & $\geq .90$ acceptable fit, $\geq .95$ good fit, $\geq .97$ perfect fit \\
TLI (NNFI) & $\geq .90$ acceptable fit, $\geq .95$ good fit \\
\hline
\end{tabular}

(Brown 2006; Cokluk et al. 2012; Hu and Bentler 1999; Kelloway 2015; Kline 2011; Raykov and Marcoulides 2008; Meydan and Șeșen 2011; Schumacker and Lomax 2004; Schermelleh-Engel et al. 2003; Sümer 2000; Şimşek 2007; Tabachnick and Fidell 2013; Thompson 2004) (As cited in Savci 2017)

$\chi^{2}$, chi-Square; $d f$, degrees of freedom; RMSEA, the toot mean square error of approximation; GFI, Goodness of Fit Index; AGFI, Adjusted Goodness of Fit Index; CFI, Confirmatory Fit Index; IFI, Incremental Fit Index; TLI (NNFI), Tucker Lewis Index (Non-Normed Fit Index)]

translated into the Turkish CIGS. Two groups of four faculty members who spoke English at a good level carried out the translation process of PACS. The first group translated the items of PACS into Turkish. The second group then translated the Turkish version back into English. At this stage, the consistency between two translations was examined. The discrepancies in translations were forwarded to the translation groups leading to a consensus on the translation. Following, the Turkish PACS was drafted. At this stage, the draft form was revised as the CIGS. In the CIGS, the words "internet gaming" were used instead of the word "drinking" (e.g., "How often have you thought about internet gaming" or "How good would internet gaming make you feel?"). Four researchers conducting research into addiction examined the adapted form. The corrections proposed by the researchers were carried out. In the final stage, the CIGS was evaluated by 30 adolescents. At this stage, it was found that adolescents evaluated the scale items as "clear" and understandable.

The structural validity of CIGS was examined using both EFA and CFA. Before starting the EFA, the suitability of the data for factor analysis was examined by the Kaiser-Meyer-Olkin (KMO) coefficient and Barlett's Sphericity Test. As a result of the analyses, it was found that the data were suitable for factor analysis. Principal Component Analysis was used in EFA. The structure obtained as a result of EFA was tested with CFA. Before starting CFA, the data were examined for sample size, multiple linearity, multicollinearity, and multiple normality. Given that the data set met the assumptions of CFA, the model was tested with the covariance matrix using the Maximum Likelihood method. The model fit was examined with $\chi^{2} / \mathrm{df}$, RMSEA, GFI, CFI, IFI, and TLI (NNFI) fit indices. Commonly accepted fit indices and acceptable limits for model fit are presented in Table 2 along with a description of each acronym. Criterion validity of the CIGS was assessed with scales and questions examining digital gaming addiction, self-discipline, impulsiveness, daily internet gaming duration, and internet gaming history. The reliability of CIGS was evaluated with Cronbach $\alpha$ internal consistency reliability coefficient and corrected item total correlation coefficients. The Cronbach $\alpha$ internal consistency coefficient and corrected item total correlation coefficients were calculated in the EFA, CFA, and criterion validity samples. SPSS and AMOS programs were used to analyze the data. 


\section{Results}

\section{Pilot Study}

A pilot study was carried out on 30 adolescents (15 females and 15 males) in order to evaluate whether the CIGS was understood by adolescents. In the pilot study, the problems that adolescents may encounter while reading the scale items and instructions were evaluated. During the study, one adolescent did not understand the word craving. It was understood that the adolescent did not read the instruction. After reading the instruction, the problem was solved because the concept of craving was defined in the instruction. As a result of the pilot study, the instructions, scale items, and response options were understood by the adolescents.

\section{Scale Validity}

Exploratory Factor Analysis The structural validity of the CIGS was investigated using Exploratory Factor Analysis (EFA). An EFA was performed on the data collected from 102 adolescents (49 females and 53 males). The suitability of the data with EFA was evaluated with the Kaiser-Meyer-Olkin (KMO) coefficient and Barlett's Sphericity Test. As a result of the analysis, KMO coefficient $=.88$ and Barlett's Sphericity Test $=\chi^{2}=331.101, p<.001$ were found. These findings indicate that the data was suitable for EFA. In the second stage, EFA was performed on the five items of the CIGS using Principal Component Analysis. As a result of the analysis, it was found that the CIGS had a single-factor structure with an Eigenvalue of 3.683. The single-factor structure of CIGS accounted for $73.7 \%$ of the total variance. Finally, a scree plot was analyzed. When the line graph presented in Fig. 1 is examined, it can be seen that the graph continues in a horizontal plane after the first break. Factor loading values of the CIGS were ranged between .77 and .90 . The scree plot of the CIGS is presented in Fig. 1, and the EFA results are shown in Table 3.

Confirmatory Factor Analysis The unidimensional CIGS model obtained as a result of EFA was then tested with Confirmatory Factor Analysis (CFA). CFA was performed on 103 adolescents (35 females and 68 males). The model was tested with the first-level CFA. As a result of the CFA, it was found that the model had acceptable fit values $\left[\chi^{2}=9.115, \mathrm{df}=5, \chi^{2}\right.$ $\mathrm{df}=1.823$, RMSEA $=.090, \mathrm{GFI}=.97, \mathrm{AGFI}=.90, \mathrm{CFI}=.99, \mathrm{IFI}=.99$, and TLI $(\mathrm{NNFI})=$ .97]. The factor loadings of the CIGS in this sample were ranged between .64 and .90 . The path diagram of the CIGS in this sample is presented in Fig. 2. The CIGS model was also tested in the criterion validity sample. As a result of the first level of CFA performed on this sample, it was found that the model had acceptable fit values (except for RMSEA) $\left[\chi^{2}=\right.$ $21.628, \mathrm{df}=5, \chi^{2} / \mathrm{df}=4.326$, RMSEA $=.159, \mathrm{GFI}=.95$, AGFI $=.85, \mathrm{CFI}=.97$, IFI $=.97$, and TLI $(\mathrm{NNFI})=.93$ ] . The factor loading values of the CIGS in this sample ranged between .67 and .93. The path diagram of CIGS in this sample is presented in Fig. 3. As a result, it was found that the five-item unidimensional structure of the CIGS was confirmed in two different samples. The CFA results are shown in Table 4.

Criteria Validation Criterion validity of the CIGS was assessed using measures of digital gaming addiction, self-discipline, impulsiveness, daily Internet gaming duration, and Internet gaming history. The CIGS, DGAS-7, BSCS, and a Personal Information Form were administered to adolescents. The criterion validity of the CIGS was carried out on a sample of 133 


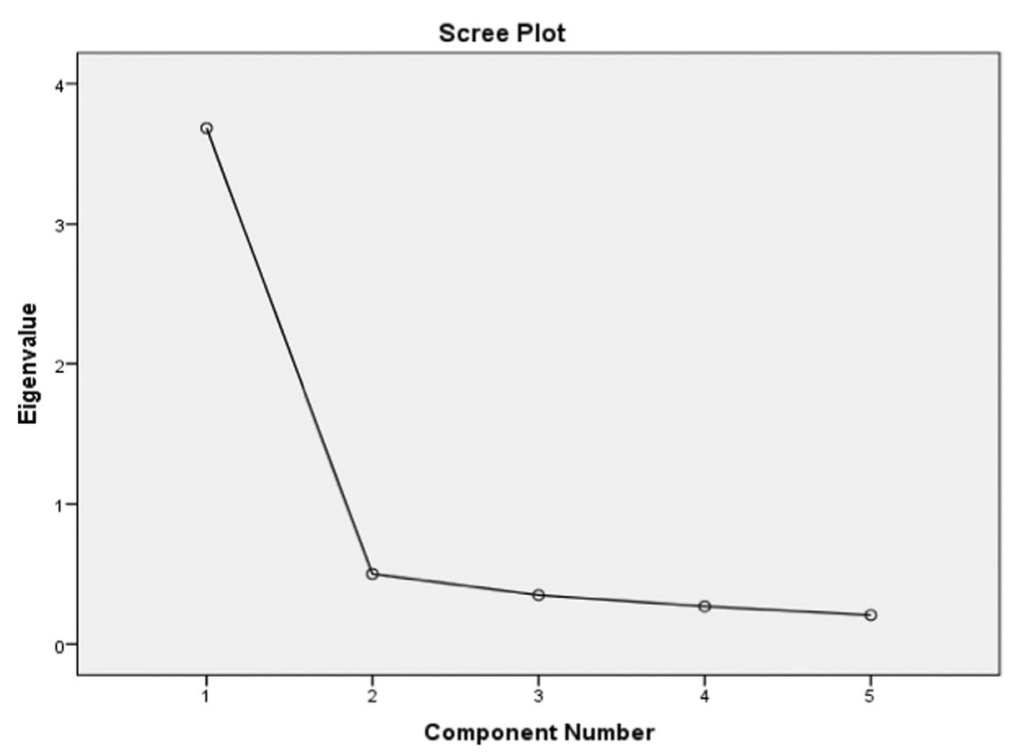

Fig. 1 The scree plot of the CIGS

adolescents (70 females and 60 males). The relationship between CIGS and digital gaming addiction, self-discipline, impulsiveness, daily internet gaming duration, and internet gaming history was analyzed using Pearson's Moments Multiplication Correlation Analysis. The analysis demonstrated that the CIGS was significantly associated with daily internet gaming duration $(r=.65, p<.01)$, internet gaming history $(r=.51, p<.01)$, impulsiveness $(r=.40$, $p<.01)$, self-discipline $(r=-.29, p<.01)$, and digital game addiction $(r=.73, p<.01)$.

\section{Scale Reliability}

The reliability of the CIGS was evaluated with Cronbach $\alpha$ internal consistency reliability coefficient and corrected item total correlation coefficients. The Cronbach $\alpha$ internal consistency reliability coefficient and corrected item total correlation coefficients were calculated across the three samples (EFA, CFA, and criterion validity). Cronbach $\alpha$ internal consistency coefficients of the CIGS were calculated as .91, .88, and .91, respectively. Correlated item total correlation coefficients of the CIGS were between .66 and .83 in the EFA sample, .61 and .83 in the CFA sample, and .68 to .86 in the criterion validity sample. These findings demonstrate that CIGS provides reliable results across different samples.

Table 3 The EFA results of CIGS

\begin{tabular}{lllll}
\hline & Items & Factor loading & \% of variance & Eigenvalue \\
\hline CIGS & 1 & .87 & 73.66 & 3.36 \\
& 2 & .89 & & \\
& 3 & .77 & & \\
& .86 & .90 & & \\
& 5 & & & \\
\hline
\end{tabular}



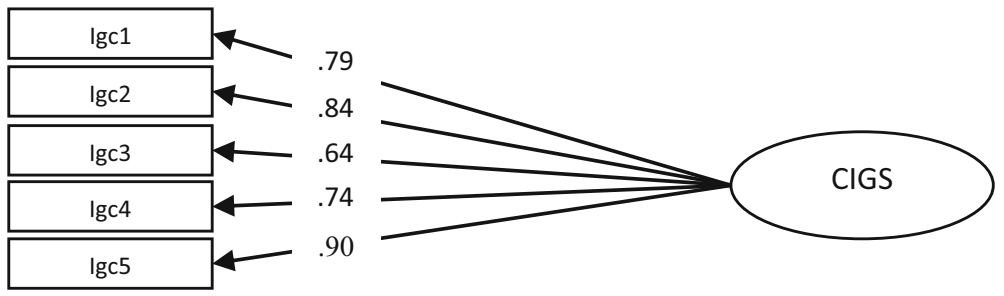

Fig. 2 Model of CIGS in the first sample

\section{Discussion}

The aim of the present study was to develop the Craving for Internet Gaming Scale (CIGS) by adapting the Penn Alcohol Craving Scale. The structural validity of CIGS was evaluated using both EFA and CFA. Furthermore, the criterion validity of the CIGS was evaluated with DGAS-7, BSCS, daily internet gaming duration, and internet gaming history. The reliability of CIGS was evaluated with Cronbach $\alpha$ internal consistency reliability coefficient and corrected item total correlation coefficients. Results of the EFA and CFA demonstrated that the CIGS has a unidimensional structure. In fact, the unidimensional structure of CIGS explained $73 \%$ of the total variance and is more than sufficient for unidimensional scales given that $30 \%$ variance in unidimensional scales is considered sufficient (Buyukozturk 2010; Cokluk et al. 2012). When the factor loadings of the items were examined, it was shown that they were sufficient across all three samples (EFA, CFA, and criterion validity). Factor loading values are accepted as $>.30$ (Kline 1994) or $>.32$ (Tabachnick and Fidell 2013). The singlefactor structure obtained as a result of the EFA was tested with CFA in two separate samples. As a result of CFA, the single-factor CIGS model had good fit values in both samples. Additionally, the fit index values in Table 2 also demonstrate acceptable values.

The criterion validity of the CIGS was assessed by examining digital gaming addiction, self-discipline, impulsiveness, daily internet gaming duration, and internet gaming history. Analysis, again demonstrated that the CIGS was associated with all these variables in the expected direction (i.e., craving was correlated with gaming addiction, impulsivity, poor selfdiscipline, and high daily internet use). The reliability of the CIGS was evaluated with Cronbach $\alpha$ internal consistency reliability coefficient. In the social sciences, an internal consistency reliability coefficient of .70 and above is considered sufficient for such scales (Cokluk et al. 2012). Again, in the present study, the CIGS coefficients were more than sufficient. More specifically, internal consistency coefficients and corrected item total correlation coefficients of the CIGS across all three samples were in the range of acceptable values

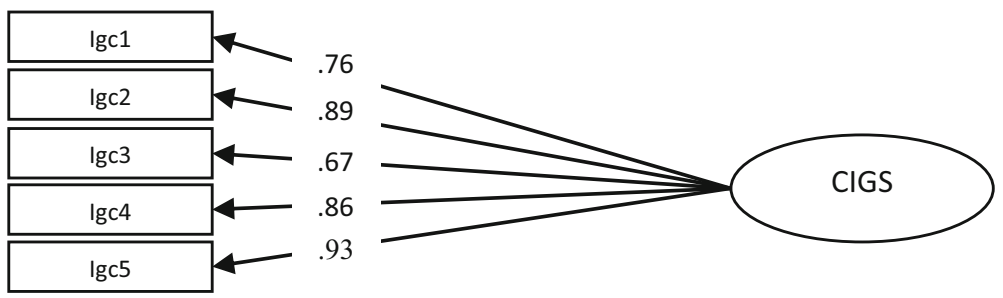

Fig. 3 Model of CIGS in the second sample 
Table 4 The CFA results of CIGS

\begin{tabular}{|c|c|c|c|c|c|c|}
\hline & \multicolumn{3}{|c|}{ CFA sample } & \multicolumn{3}{|c|}{ Criterion validity sample } \\
\hline & $\lambda$ & $R^{2}$ & $t$ & $\lambda$ & $R^{2}$ & $t$ \\
\hline $\mathrm{CIGS} \rightarrow \mathrm{Igc} 1$ & .79 & .62 & 9.928 & .76 & .58 & 11.579 \\
\hline $\mathrm{CIGS} \rightarrow \mathrm{Igc} 2$ & .84 & .70 & 10.975 & .89 & .78 & 16.085 \\
\hline $\mathrm{CIGS} \rightarrow \operatorname{Igc} 3$ & .64 & .41 & 7.280 & .67 & .45 & 9.428 \\
\hline $\mathrm{CIGS} \rightarrow \operatorname{Igc} 4$ & .74 & .55 & 9.090 & .86 & .73 & 14.848 \\
\hline $\mathrm{CIGS} \rightarrow \operatorname{Igc} 5$ & .90 & .81 & & .93 & .87 & \\
\hline
\end{tabular}

found in the literature. The findings of the present study indicate that CIGS is a valid and reliable scale for assessing craving among gamers.

Digital technologies are now used extensively worldwide (Kemp 2018). As the use of digital technologies increases, an increasing minority of individuals have been shown to display problematic behavior related to such technologies (Kuss et al. 2014). Indeed, it appears that every new digital technology and platform produces a small minority of individuals that experience problems relating to the technology that some scholars describe as addictions (e.g., Kuss and Griffiths 2017; Savci and Aysan 2018). The first paper published on internet addiction was by Griffiths (1996b) who, like Young (1998), used it to describe individuals who spent hours a day online to the neglect of everything else in their lives.

However, over two decades later, the term is an umbrella term used primarily to describe addictions on the Internet rather than to the Internet. Words like "addictive," "compulsive," "pathological," and "problematic" are now used alongside Internet and smartphone use generally (e.g., Kwon et al. 2013; Lei and Yang 2007; Meerkerk et al. 2009; Panda and Jain 2018; Saidon et al. 2016; Shapira et al. 2003; Takao et al. 2009; Young 1998), as well as specific online activities such as social media use (e.g., Aladwani and Almarzouq 2016; Griffiths and Szabo 2014; Kuss and Griffiths 2017; Lee and Cheung 2014; Savci et al. 2018), online gambling (APA 2013; WHO 2016), online shopping (Rose and Dhandayudham 2014), online pornography (Owens et al. 2012), online sex (Griffiths 2001), phubbing (Karadağ et al. 2016), cyberbullying (Campbell 2005), fear of missing out (Elhai et al. 2016), phantom ringing, phantom vibration, and phantom texts/notifications (Chen et al. 2014; Drouin et al. 2012; Kruger and Djerf 2016; Lin et al. 2013). Subdivisions of these potentially addictive and/or problematic behaviors and other new potentially problematic online behaviors appear to be growing annually. At present, only IGD is officially recognized in some form (APA 2013; WHO 2016). However, the number of disorders diagnosed in the future may increase as the number of people who use the Internet and smartphones increases. The concept of craving presented here relating to gaming use could also be applied for other online problematic disorders related to digital technology use. Therefore, craving is very important for these disorders.

The validity and reliability of the CIGS were performed on adolescent samples. Given that adolescents appear to be more vulnerable to IGD (Kuss and Griffiths 2012), the sample is arguably appropriate. Furthermore, all the analyses regarding the validity and reliability of the CIGS increased its measurement power. The newly developed CIGS may facilitate increased research into craving among gamers for intercultural use. The PACS is already used in many cultures and it is hoped the CIGS can do the same. There are of course limitations to the present study. The CIGS is a self-report scale and self-report is 
open to well-known biases such as memory recall and social desirability biases (although this cannot be overcome when using psychometric testing as all data are self-report). The reliability and validity of CIGS were also carried out using non-clinical samples because the scale was validated using a convenience sample of students. Therefore, future studies will need to test the scale's utility using clinical samples (as well as comparing clinical and non-clinical samples). Furthermore, the validity and reliability of the CIGS were carried out on adolescents studying at high schools which may have meant some types of adolescents were not included in the analysis (e.g., non-traditional students in special needs schools and students who regularly truant). The present study also used convenience sampling method with a modest sample size based on Turkish adolescents. This limits the representation of the sample. Therefore, future research should use bigger and more representative (and random) samples from other countries and cultures. Furthermore, the present study did not include test-retest reliability. Despite these limitations, the validity and reliability of the CIGS was psychometrically robust. The CIGS's criterion validity should also be evaluated with scales based on objective assessment tools. Future CIGS studies should also examine different adolescent groups as well as emerging and older adults.

\section{Compliance with Ethical Standards}

Ethics Committee Approval Ethics committee approval was obtained for this study. The authors report that the study was conducted in accordance with the Helsinki Declaration.

Informed Consent The Informed Consent Form was read by the researcher in the classroom environment.

Conflict of Interest The authors declare that they have no conflict of interest.

\section{Appendix 1. İnternette Oyun Oynama Aşerme Ölçeği (IOOAÖ) (Turkish)}

$\mathrm{Bu}$ araştırma internette oyun oynama isteğinizi değerlendirmek amacıyla gerçekleștirilmektedir. Lütfen her maddeyi dikkatlice okuyun ve son bir haftayı dikkate alarak, internette oyun așermenizi (internette oyun oynama isteğinizi) en iyi tanımlayan seçeneği isaretleyin.

1. Son bir haftayı dikkate aldığınızda, internette oyun oynamak ile ilgili ya da internette oyun oynamanın sizi ne kadar iyi hissettireceği ile ilgili ne sıklıkta düşündünüz?

(O) Hiç (geçtiğimiz hafta içinde 0 defa)

(1) Nadiren (geçtiğimiz hafta içinde 1-2 defa)

(2) Ara sıra (geçtiğimiz hafta içinde 3-4 defa)

(3) Bazen (geçtiğimiz hafta içinde 5 ila 10 defa veya günde 1-2 defa)

(4) Siklıkla (geçtiğimiz hafta içinde 11-20 defa veya günde 2-3 defa)

(5) Çoğu zaman (geçtiğimiz hafta içinde 20-40 defa veya günde 3-6 defa)

(6) Neredeyse her zaman (geçtiğimiz hafta içinde 40 defadan fazla veya günde 6 defadan fazla)

2. Son bir haftayı dikkate aldığınızda, en șiddetli noktasında, internette oyun oynama așermeniz ne kadar güçlüydü?

(O) Hiç istek yoktu

(1) Önemsenmeyecek düzeyde, yani çok hafif istek

(2) Hafif istek

(3) Orta düzeyde istek

(4) Güçlü istek, fakat kolaylıkla kontrol edildi

(5) Güçlü istek ve kontrol edilmesi zor 
(6) Güçlü istek ve kontrol edilemez

3. Son bir haftayı dikkate aldığınızda, internette oyun oynamak ile ilgili ya da internette oyun oynamanın sizi ne kadar iyi hissettireceği ile ilgili düșünmeye ne kadar zaman harcadınız?

(O) Hiç

(1) 20 dakikadan az

(2) $21-45$ dakika

(3) $46-90$ dakika

(4) 90 dakika -3 saat

(5) 3-6 saat arası

(6) 6 saatten daha fazla

4. Son bir haftayı dikkate aldığınızda, eğer internette oyun oynama imkânınız olduğunu bilseydiniz internette oyun oynamaya direnmek ne kadar zor olurdu?

(0) Hiç zor olmazdı

(1) Çok hafif zor

(2) Hafif zor

(3) Orta zorlukta

(4) Çok zor

(5) Așirı zor

(6) Karșı koyamazdım

5. Önceki sorulara verdiğiniz cevapları aklınızda tutarak, lütfen son bir hafta için ortalama internette oyun oynama aşermenizi değerlendirin.

(0) Hiç oynama düşüncem olmadı ve hiç oynama isteğim olmadı.

(1) Nadiren oynamayla ilgili düșündüm ve nadiren oynama isteğim oldu.

(2) Ara sıra oynamayla ilgili düșündüm ve ara sıra oynama isteğim oldu.

(3) Bazen oynamayla ilgili düşündüm ve bazen oynama isteğim oldu.

(4) Siklıkla oynamayla ilgili düșündüm ve sıklıkla oynama isteğim oldu.

(5) Çoğu zaman oynamayla ilgili düșündüm ve çoğu zaman oynama isteğim oldu.

(6) Neredeyse her zaman oynamayla ilgili düșündüm ve neredeyse her zaman oynama isteğim oldu.

\section{Appendix 2. Craving for İnternet Gaming Scale (CIGS)}

This research is carried out to evaluate your craving for internet gaming (desire for internet gaming). Please read the following questions and choose the option that suits you. Please consider the option for each question that best describes your craving for Internet gaming over the past week

1. In the past week, how often have you thought about internet gaming or about how good internet gaming would make you feel?

(O) Never, that is, 0 times during this period of time.

(1) Rarely, that is, 1 to 2 times during this period of time.

(2) Occasionally, that is, 3 to 4 during this period of time.

(3) Sometimes, that is, 5 to 10 times during this period or 1 to 2 times a day.

(4) Often, that is, 11 to 20 times during this period or 2 to three times a day.

(5) Most of the time, that is, 20 to 40 during this period or 3 to 6 times a day.

(6) Nearly all of the time, that is, more than 40 times during this period or more than 6 times a day.

2. In the past week at its most severe point, how strong was your craving for internet gaming?

(0) None at all.

(1) Slight, that is a very mild urge.

(2) Mild urge.

(3) Moderate urge.

(4) Strong urge, but easily controlled.

(5) Strong urge and difficult to control.

(6) Strong urge and uncontrollable.

3. In the past week, how much time have you spent thinking about internet gaming or about how good internet gaming would make you feel?

(O) None at all. 
(1) Less than 20 minutes.

(2) 21-45 minutes.

(3) 46-90 minutes.

(4) 90 minutes- 3 hours.

(5) Between 3 to 6 hours.

(6) More than 6 hours.

4. In the past week, how difficult would it have been to resist internet gaming if you knew you had the opportunity to engage in internet gaming?

(O) Not difficult at all.

(1) Very mildly difficult.

(2) Mildly difficult.

(3) Moderately difficult.

(4) Very difficult.

(5) Extremely difficult.

(6) Would not be able to resist.

5. Keeping in mind your responses to the previous questions, please rate your overall average craving for internet gaming during the past week.

(0) Never thought about internet gaming and never had the urge to internet gaming.

(1) Rarely thought about internet gaming and rarely had the urge to internet gaming.

(2) Occasionally thought about internet gaming and occasionally had the urge to internet gaming.

(3) Sometimes thought about internet gaming and sometimes had the urge to internet gaming.

(4) Often thought about internet gaming and often had the urge to internet gaming.

(5) Thought about internet gaming most of the time and had the urge to internet gaming most of the time.

(6) Thought about internet gaming nearly all of the time and had the urge to internet gaming nearly all of the time.

\section{Appendix 3. Penn Alcohol Craving Scale (PACS)}

Circle the most appropriate number for each item. If this is the first time you are filling out this form, the questions apply to the last week that you drank any alcohol. If you received Serax or another medication for detoxification, exclude that time period. If you are currently participating in the medication trial, these questions cover the time period from the day of your last visit to the day before your current visit

1. How often have you thought about drinking or about how good a drink would make you feel during this period?

(0) Never, that is, 0 times during this period of time.

(1) Rarely, that is, 1 to 2 times during this period of time.

(2) Occasionally, that is, 3 to 4 during this period of time.

(3) Sometimes, that is, 5 to 10 times during this period or 1 to 2 times a day.

(4) Often, that is, 11 to 20 times during this period or 2 to three times a day.

(5) Most of the time, that is, 20 to 40 during this period or 3 to 6 times a day.

(6) Nearly all of the time, that is, more than 40 times during this period or more than 6 times a day.

2. At its most severe point, how strong was your craving during this period?

(a) None at all.

(1) Slight, that is a very mild urge.

(2) Mild urge.

(3) Moderate urge.

(4) Strong urge, but easily controlled.

(5) Strong urge and difficult to control.

(6) Strong urge and would have drunk alcohol if it were available.

3. How much time have you spent thinking about drinking or about how good a drink would make you feel during this period?

(a) None at all.

(1) Less than 20 minutes.

(2) 21-45 minutes.

(3) 46-90 minutes. 
(4) 90 minutes-3 hours.

(5) Between 3 to 6 hours.

(6) More than 6 hours.

4. How difficult would it have been to resist taking a drink during this period of time if you had known a bottle were in your house?

(O) Not difficult at all.

(1) Very mildly difficult.

(2) Mildly difficult.

(3) Moderately difficult.

(4) Very difficult.

(5) Extremely difficult.

(6) Would not be able to resist.

5. Keeping in mind your responses to the previous questions, please rate your overall average alcohol craving for the stated period of time.

(0) Never thought about drinking and never had the urge to drink.

(1) Rarely thought about drinking and rarely had the urge to drink.

(2) Occasionally thought about drinking and occasionally had the urge to drink.

(3) Sometimes thought about drinking and sometimes had the urge to drink.

(4) Often thought about drinking and often had the urge to drink.

(5) Thought about drinking most of the time and had the urge to drink most of the time.

(6) Thought about drinking nearly all of the time and had the urge to drink nearly all of the time.

Open Access This article is distributed under the terms of the Creative Commons Attribution 4.0 International License (http://creativecommons.org/licenses/by/4.0/), which permits unrestricted use, distribution, and reproduction in any medium, provided you give appropriate credit to the original author(s) and the source, provide a link to the Creative Commons license, and indicate if changes were made.

\section{References}

Aladwani, A. M., \& Almarzouq, M. (2016). Understanding compulsive social media use: The premise of complementing self-conceptions mismatch with technology. Computers in Human Behavior, 60, 575-581. https://doi.org/10.1016/j.chb.2016.02.098.

American Psychiatric Association (APA). (2013). Diagnostic and Statistical Manual of Mental Disorders-5 (DSM-5). Arlington VA: American Psychiatric Publishing.

Andreassen, C. S., Griffiths, M. D., Pallesen, S., Bilder, R. M., Torsheim, T., \& Aboujaoude, E. (2015). The Bergen shopping addiction scale: Reliability and validity of a brief screening test. Frontiers in Psychology, 6. https://doi.org/10.3389/fpsyg.2015.01374.

Aricak, O. T., Dinc, M., Yay, M., \& Griffiths, M. D. (2018). Adapting the short form of the Internet gaming disorder scale into Turkish: Validity and reliability. Addicta: The Turkish Journal on Addictions, 5(4), 615636. https://doi.org/10.15805/addicta.2018.5.4.0027.

Bargeron, A. H., \& Hormes, J. M. (2017). Psychosocial correlates of internet gaming disorder: Psychopathology, life satisfaction, and impulsivity. Computers in Human Behavior, 68, 388-394. https://doi.org/10.1016/j. chb.2016.11.029.

Bohn, M. J., Krahn, D. D., \& Staehler, B. A. (1995). Development and initial validation of a measure of drinking urges in abstinent alcoholics. Alcoholism: Clinical and Experimental Research, 19(3), 600-606. https://doi. org/10.1111/j.1530-0277.1995.tb01554.x.

Brown, T. A. (2006). Confirmatory factor analysis for applied research. New York: Guilford Press.

Buyukozturk, Ș. (2010). Manual of data analysis for social sciences. (in Turkish). Ankara: Pegem Publishing.

Campbell, M. A. (2005). Cyber bullying: An old problem in a new guise? Australian Journal of Guidance and Counselling, 15(01), 68-76. https://doi.org/10.1375/ajgc.15.1.68.

Chen, C. P., Wu, C. C., Chang, L. R., \& Lin, Y. H. (2014). Possible association between phantom vibration syndrome and occupational burnout. Neuropsychiatric Disease and Treatment, 10, 2307-2314. https://oi. org/10.2147/ndt.s73038. 
Cheng, C., Cheung, M. W.-L., \& Wang, H. (2018). Multinational comparison of internet gaming disorder and psychosocial problems versus well-being: Meta-analysis of 20 countries. Computers in Human Behavior, 88, 153-167. https://doi.org/10.1016/j.chb.2018.06.033.

Chodkiewicz, J., Ziółkowski, M., Czarnecki, D., Gąsior, K., Juczyński, A., Biedrzycka, B., \& NowakowskaDomagała, K. (2018). Validation of the Polish version of the Penn Alcohol Craving Scale (PACS). Psychiatria Polska, 52(2), 399-410. https://doi.org/10.12740/pp/onlinefirst/40548.

Cokluk, Ö., Sekercioglu, G., \& Buyukozturk, Ș. (2012). Multivariate SPSS and LISREL applications for social sciences. (in Turkish). Ankara: Pegem Publishing.

Dong, G., Wang, L., Du, X., \& Potenza, M. N. (2017). Gaming increases craving to gaming-related stimuli in individuals with internet gaming disorder. Biological Psychiatry: Cognitive Neuroscience and Neuroimaging, 2(5), 404-412. https://doi.org/10.1016/j.bpsc.2017.01.002.

Drouin, M., Kaiser, D. H., \& Miller, D. A. (2012). Phantom vibrations among undergraduates: Prevalence and associated psychological characteristics. Computers in Human Behavior, 28(4), 1490-1496. https://oi. org/10.1016/j.chb.2012.03.013.

Elhai, J. D., Levine, J. C., Dvorak, R. D., \& Hall, B. J. (2016). Fear of missing out, need for touch, anxiety and depression are related to problematic smartphone use. Computers in Human Behavior, 63, 509-516. https://doi.org/10.1016/j.chb.2016.05.079.

Evren, C., Flannery, B., Çelik, R., Durkaya, M., \& Dalbudak, E. (2008). Reliability and validity of Turkish version the Penn Alcohol Craving Scale (PACS) in male alcohol dependent inpatients. Journal of Dependence, 9(3), 128-134.

Feng, W., Ramo, D. E., Chan, S. R., \& Bourgeois, J. A. (2017). Internet gaming disorder: Trends in prevalence 1998-2016. Addictive Behaviors, 75, 17-24. https://doi.org/10.1016/j.addbeh.2017.06.010.

Flannery, B. A., Volpicelli, J. R., \& Pettinati, H. M. (1999). Psychometric properties of the Penn Alcohol Craving Scale. Alcoholism: Clinical \& Experimental Research, 23(8), 1289-1295. https://doi.org/10.1097 /00000374-199908000-00001.

Freeman, C. B. (2008). Internet gaming addiction. Journal for Nurse Practitioners, 4(1), 42-47. https://oi. org/10.1016/j.nurpra.2007.10.006.

Gearhardt, A. N., Corbin, W. R., \& Brownell, K. D. (2009). Preliminary validation of the Yale Food Addiction Scale. Appetite, 52(2), 430-436. https://doi.org/10.1016/j.appet.2008.12.003.

Gervasi, A. M., La Marca, L., Costanzo, A., Pace, U., Guglielmucci, F., \& Schimmenti, A. (2017). Personality and internet gaming disorder: A systematic review of recent literature. Current Addiction Reports, 4(3), 293307. https://doi.org/10.1007/s40429-017-0159-6.

González-Bueso, V., Santamaría, J. J., Fernández, D., Merino, L., Montero, E., Jiménez-Murcia, S., ... Ribas, J. (2018). Internet gaming disorder in adolescents: Personality, psychopathology and evaluation of a psychological intervention combined with parent psychoeducation. Frontiers in Psychology, 9, 787. https://oi. org/10.3389/fpsyg.2018.00787.

Grant, J. E., Potenza, M. N., Weinstein, A., \& Gorelick, D. A. (2010). Introduction to behavioral addictions. American Journal of Drug and Alcohol Abuse, 36(5), 233-241. https://doi.org/10.3109 /00952990.2010.491884.

Griffiths, M. (1996a). Behavioural addiction: An issue for everybody? Employee Counselling Today, 8(3), 19-25. https://doi.org/10.1108/13665629610116872.

Griffiths, M. D. (1996b). Internet addiction: An issue for clinical psychology? Clinical Psychology Forum, 97, 32-36.

Griffiths, M. (2001). Sex on the internet: Observations and implications for internet sex addiction. Journal of Sex Research, 38(4), 333-342. https://doi.org/10.1080/00224490109552104.

Griffiths, M. (2005). A "components" model of addiction within a biopsychosocial framework. Journal of Substance Use, 10(4), 191-197. https://doi.org/10.1080/14659890500114359.

Griffiths, M. D., \& Szabo, A. (2014). Is excessive online usage a function of medium or activity? Journal of Behavioral Addictions, 3(1), 74-77. https://doi.org/10.1556/jba.2.2013.016.

Griffiths, M., Kuss, D. J., \& King, D. L. (2012). Video game addiction: Past, present and future. Current Psychiatry Reviews, 8(4), 308-318. https://doi.org/10.2174/157340012803520414.

Hawi, N. S., Samaha, M., \& Griffiths, M. D. (2018). Internet gaming disorder in Lebanon: Relationships with age, sleep habits, and academic achievement. Journal of Behavioral Addictions, 7(1), 70-78. https://doi. org/10.1556/2006.7.2018.16.

Holden, C. (2001). "Behavioral” addictions: Do they exist? Science, 294(5544), 980-982. https://doi.org/10.1126 /science.294.5544.980.

Hu, L., \& Bentler, P. M. (1999). Cutoff criteria for fit indexes in covariance structure analysis: Conventional criteria versus new alternatives. Structural Equation Modeling, 6(1), 1-55.

Karadağ, E., Tosuntaş, Ș. B., Erzen, E., Duru, P., Bostan, N., Mizrak Șahin, B., et al. (2016). The virtual World's current addiction: Phubbing. Addicta: The Turkish Journal on Addictions, 3(2), 250-269. https://doi. org/10.15805/addicta.2016.3.0013. 
Kavanagh, D. J., Statham, D. J., Feeney, G. F. X., Young, R. M., May, J., Andrade, J., \& Connor, J. P. (2013). Measurement of alcohol craving. Addictive Behaviors, 38(2), 1572-1584. https://doi.org/10.1016/j. addbeh.2012.08.004.

Kelloway, E. K. (2015). Using Mplus for structural equation modeling: A researcher's guide. (2th ed.). London: Sage.

Kemp, S. (2018). Digital in 2018. Retrieved July 15, 2019, from: https://wearesocial.com/blog/2018/01/globaldigital-report-2018.

Kim, M. J., Kim, S. G., Kim, H. J., Kim, H. C., Park, J. H., Park, K. S., Lee, D. K., Byun, W. T., \& Kim, C. M. (2008). A study of the reliability and validity of the Korean version of the Penn Alcohol Craving Scale for alcohol-dependent patients. Psychiatry Investigation, 5(3), 175-183. https://doi.org/10.4306 /pi.2008.5.3.175.

Kim, Y.-J., Lim, J. A., Lee, J. Y., Oh, S., Kim, S. N., Kim, D. J., Ha, J. E., Kwon, J. S., \& Choi, J.-S. (2017). Impulsivity and compulsivity in Internet gaming disorder: A comparison with obsessive-compulsive disorder and alcohol use disorder. Journal of Behavioral Addictions, 6(4), 545-553. https://doi. org/10.1556/2006.6.2017.069.

Kim, H., Ha, J., Chang, W.-D., Park, W., Kim, L., \& Im, C.-H. (2018). Detection of craving for gaming in adolescents with internet gaming disorder using multimodal biosignals. Sensors, 18(2), 102. https://doi. org/10.3390/s18010102.

King, D. L., \& Delfabbro, P. H. (2014). The cognitive psychology of Internet gaming disorder. Clinical Psychology Review, 34(4), 298-308. https://doi.org/10.1016/j.cpr.2014.03.006.

King, D. L., \& Delfabbro, P. H. (2016). The cognitive psychopathology of internet gaming disorder in adolescence. Journal of Abnormal Child Psychology, 44(8), 1635-1645. https://doi.org/10.1007/s10802016-0135y.

King, D. L., Haagsma, M. C., Delfabbro, P. H., Gradisar, M., \& Griffiths, M. D. (2013). Toward a consensus definition of pathological video-gaming: A systematic review of psychometric assessment tools. Clinical Psychology Review, 33(3), 331-342. https://doi.org/10.1016/j.cpr.2013.01.002.

King, D. L., Kaptsis, D., Delfabbro, P. H., \& Gradisar, M. (2016). Craving for internet games? Withdrawal symptoms from an 84-h abstinence from massively multiplayer online gaming. Computers in Human Behavior, 62, 488-494. https://doi.org/10.1016/j.chb.2016.04.020.

Kline, P. (1994). An easy guide to factor analysis. London: Routledge.

Kline, R. B. (2011). Principles and practice of structural equation modeling (third ed.). New York: The Guilford Press.

Kruger, D. J., \& Djerf, J. M. (2016). High Ringxiety: Attachment anxiety predicts experiences of phantom cell phone ringing. Cyberpsychology, Behavior and Social Networking, 19(1), 56-59. https://doi.org/10.1089 /cyber.2015.0406.

Kuss, D. J., \& Griffiths, M. D. (2012). Internet gaming addiction: A systematic review of empirical research. International Journal of Mental Health and Addiction, 10(2), 278-296. https://oi.org/10.1007/s11469-011-9318-5.

Kuss, D., \& Griffiths, M. (2017). Social networking sites and addiction: ten lessons learned. International Journal of Environmental Research and Public Health, 14(3), 311. https://doi. org/10.3390/ijerph14030311.

Kuss, D. J., Griffiths, M. D., Karila, L., \& Billieux, J. (2014). Internet addiction: A systematic review of epidemiological research for the last decade. Current Pharmaceutical Design, 20, 4026-4052.

Kwon, M., Lee, J.-Y., Won, W.-Y., Park, J.-W., Min, J.-A., Hahn, C., Gu, X., Choi, J. H., \& Kim, D.-J. (2013). Development and validation of a smartphone addiction scale (SAS). PLoS One, 8(2), e56936. https://doi. org/10.1371/journal.pone.0056936.

Lam, L. T. (2014). Internet gaming addiction, problematic use of the internet, and sleep problems: A systematic review. Current Psychiatry Reports, 16(444). doi:https://doi.org/10.1007/s11920-014-0444-1.

Lee, Z. W. Y., \& Cheung, C. M. K. (2014). Problematic use of social networking sites: The role of self-esteem. International Journal of Business and Information, 9(2), 143-159.

Lei, L., \& Yang, Y. (2007). The development and validation of adolescent pathological internet use scale. Acta Psychologica, 39(4), 688-696.

Lemmens, J. S., Valkenburg, P. M., \& Peter, J. (2009). Development and validation of a game addiction scale for adolescents. Media Psychology, 12(1), 77-95.

Lin, Y.-H., Chen, C.-Y., Li, P., \& Lin, S.-H. (2013). A dimensional approach to the phantom vibration and ringing syndrome during medical internship. Journal of Psychiatric Research, 47(9), 1254-1258. https://doi. org/10.1016/j.jpsychires.2013.05.023.

McLellan, A. T., Luborsky, L., Woody, G. E., \& O’brien, C. P. (1980). An improved diagnostic evaluation instrument for substance abuse patients: The Addiction Severity Index. Journal of Nervous and Mental Disease, 21, 28-33. https://doi.org/10.1097/00005053-198001000-00006 
Meerkerk, G.-J., Van Den Eijnden, R. J. J. M., Vermulst, A. A., \& Garretsen, H. F. L. (2009). Compulsive Internet Use Scale. Cyberpsychology \& Behavior, 12(1), 1-6. https://doi.org/10.1037/t34789-000.

Meydan, C. H., \& Șeșen, H. (2011). Yapısal eşitlik modellemesi AMOS uygulamaları. Ankara: Detay Yayıncılık.

Miller, W. R., Tonigan, J. S., \& Longabaugh, R. (1995). The Drinker Inventory of Consequences (DrlnC): An Instrument for Assessing Adverse Consequences of Alcohol Abuse Test Manual. NIAAA Project MATCH Monograph Scrics, Vol. 4, NIH pub. No. 95-3911. Washington, DC: US Government Printing Office.

Modell, J. G., Glaser, F. B., Cyr, L., \& Mountz, J. M. (1992). Obsessive and compulsive characteristics of craving for alcohol in alcohol abuse and dependence. Alcoholism: Clinical and Experimental Research, 16(2), 272274. https://doi.org/10.1111/j.1530-0277.1992.tb01375.x.

Moreyra, P., Ibáñez, A., Liebowitz, M. R., Sáiz-Ruiz, J., \& Blanco, C. (2002). Pathological gambling: Addiction or obsession? Psychiatric Annals, 32(3), 161-166. https://doi.org/10.3928/0048-5713-20020301-05.

Nebioglu, M., Konuk, N., Akbaba, S., \& Eroglu, Y. (2012). The investigation of validity and reliability of the Turkish version of the Brief Self-Control Scale. Bulletin of Clinical Psychopharmacology, 22(4), 340-351.

Owens, E. W., Behun, R. J., Manning, J. C., \& Reid, R. C. (2012). The impact of internet pornography on adolescents: A review of the research. Sexual Addiction \& Compulsivity, 19(1-2), 99-122. https://doi. org/10.1080/10720162.2012.660431.

Panda, A., \& Jain, N. K. (2018). Compulsive smartphone usage and users' ill-being among young Indians: Does personality matter? Telematics and Informatics, 35(5), 1355-1372. https://doi.org/10.1016/j.tele.2018.03.006.

Pérez Gálvez, B., De Juan-Gutiérrez Maroto, J., García Fernández, L., Cabot Ivorra, N., \& De Vicente Manzanaro, M. P. (2016). Validación de tres instrumentos de evaluación del craving al alcohol en una muestra española: PACS, OCDS5 y ACQ-SF-R. Health and Addictions/Salud y Drogas, 16(2), 73-79. https://doi.org/10.21134/haaj.v16i2.260.

Pontes, H. (2016). Current practices in the clinical and psychometric assessment of internet gaming disorder in the era of the DSM-5: A mini review of existing assessment tools. Mental Health and Addiction Research, 1(1), 18-19. https://doi.org/10.15761/mhar.1000105.

Raykov, T., \& Marcoulides, G. A. (2008). An introduction to applied multivariate analysis. New York: Routledge.

Rose, S., \& Dhandayudham, A. (2014). Towards an understanding of Internet-based problem shopping behaviour: the concept of online shopping addiction and its proposed predictors. Journal of Behavioral Addictions, 3(2), 83-89. https://doi.org/10.1556/jba.3.2014.003.

Ryu, H., Lee, J.-Y., Choi, A., Park, S., Kim, D.-J., \& Choi, J.-S. (2018). The relationship between impulsivity and internet gaming disorder in young adults: Mediating effects of interpersonal relationships and depression. International Journal of Environmental Research and Public Health, 15(3), 458. https://doi.org/10.3390 /ijerph15030458.

Sahin, M., Gumus, Y. Y., \& Dincel, S. (2014). Game addiction and academic achievement. Educational Psychology, 36(9), 1533-1543. https://doi.org/10.1080/01443410.2014.972342.

Saidon, J., Musa, R., Harun, M. H. M., \& Adam, A. A. (2016). The conceptual framework of pathological smartphone use (PSU). Procedia Economics and Finance, 37, 426-431. https://doi.org/10.1016/s2212-5671(16)30147-2.

Sarda, E., Bègue, L., Bry, C., \& Gentile, D. (2016). Internet gaming disorder and well-being: a scale validation. Cyberpsychology, Behavior and Social Networking, 19(11), 674-679. https://oi.org/10.1089/cyber.2016.0286.

Saunders, J. B., Hao, W., Long, J., King, D. L., Mann, K., Fauth-Bühler, M., Rumpf, H. J., Bowden-Jones, H., Rahimi-Movaghar, A., Chung, T., Chan, E., Bahar, N., Achab, S., Lee, H. K., Potenza, M., Petry, N., Spritzer, D., Ambekar, A., Derevensky, J., Griffiths, M. D., Pontes, H. M., Kuss, D., Higuchi, S., Mihara, S., Assangangkornchai, S., Sharma, M., Kashef, A. E., Ip, P., Farrell, M., Scafato, E., Carragher, N., \& Poznyak, V. (2017). Gaming disorder: Its delineation as an important condition for diagnosis, management, and prevention. Journal of Behavioral Addictions, 6(3), 271-279. https://doi.org/10.1556/2006.6.2017.039.

Sauvaget, A., Trojak, B., Bulteau, S., Jiménez-Murcia, S., Fernández-Aranda, F., Wolz, I., Menchón, J. M., Achab, S., Vanelle, J. M., \& Grall-Bronnec, M. (2015). Transcranial direct current stimulation (tDCS) in behavioral and food addiction: A systematic review of efficacy, technical, and methodological issues. Frontiers in Neuroscience, 9, 349. https://doi.org/10.3389/fnins.2015.00349.

Savci, M. (2017). Relationships among relational social connectedness, internet addiction, peer relations, social anxiety and social intelligence levels of adolescents. (Doctoral thesis). Dokuz Eylul University, Institute of Educational Sciences, Izmir.

Savci, M., \& Aysan, F. (2017). Technological addictions and social connectedness: Predictor effect of Internet addiction, social media addiction, digital game addiction and smartphone addiction on social connectedness. Dusunen Adam: The Journal of Psychiatry and Neurological Sciences, 30(3), 202-216. https://doi. org/10.5350/dajpn2017300304.

Savci, M., \& Aysan, F. (2018). \#Interpersonal competence, loneliness, fear of negative evaluation, and reward and punishment as predictors of social media addiction and their accuracy in classifying adolescent social media users and non-users. Addicta: The Turkish Journal on Addictions, 5(3), 431-471. https://doi. org/10.15805/addicta.2018.5.3.0032. 
Savci, M., Ercengiz, M., \& Aysan, F. (2018). Turkish adaptation of the Social Media Disorder Scale in adolescents. Archive of Neuropsychiatry, 55(3), 248-255. https://doi.org/10.5152/npa.2017.19285.

Schermelleh-Engel, K., Moosbrugger, H., \& Müller, H. (2003). Evaluating the fit of structural equation models: Tests of significance and descriptive goodness-of-fit measures. Methods of Psychological Research Online, $8(2), 23-74$

Schumacker, R. E., \& Lomax, R. G. (2004). A begınner's guıde to structural equatıon modeling. (2nd ed.). London: Lawrence Erlbaum Associates, Publishers.

Shapira, N. A., Lessig, M. C., Goldsmith, T. D., Szabo, S. T., Lazoritz, M., Gold, M. S., \& Stein, D. J. (2003). Problematic internet use: proposed classification and diagnostic criteria. Depression and Anxiety, 17(4), 207216. https://doi.org/10.1002/da.10094.

Shin, Y.-B., Kim, J.-J., Kim, M.-K., Kyeong, S., Jung, Y. H., Eom, H., \& Kim, E. (2018). Development of an effective virtual environment in eliciting craving in adolescents and young adults with internet gaming disorder. PLoS One, 13(4), e0195677. https://doi.org/10.1371/journal.pone.0195677.

Şimșek, Ö. F. (2007). Yapısal eşitlik modellemesine giriş: Temel ilkeler ve LISREL uygulamaları. Ankara: Ekinoks Yayıncilik.

Sümer, N. (2000). Yapısal eșitlik modelleri: Temel kavramlar ve örnek uygulamalar. Türk Psikoloji Yazıları, 3(6), 49-74.

Tabachnick, B. G., \& Fidell, L. S. (2013). Using multivariate statistics. (sixth Edition). New Jersey: Pearson Education.

Takao, M., Takahashi, S., \& Kitamura, M. (2009). Addictive personality and problematic mobile phone use. CyberPsychology \& Behavior, 12(5), 501-507. https://doi.org/10.1089/cpb.2009.0022.

Tangney, J. P., Baumeister, R. F., \& Boone, A. L. (2004). High self-control predicts good adjustment, less pathology, better grades, and interpersonal success. Journal of Personality, 72(2), 271-324. https://oi. org/10.1111/j.0022-3506.2004.00263.x.

Terry, A., Szabo, A., \& Griffiths, M. (2004). The exercise addiction inventory: A new brief screening tool. Addiction Research and Theory, 12(5), 489-499. https://doi.org/10.1080/16066350310001637363.

Thompson, B. (2004). Exploratory and confirmatory factor analysis: Understanding concepts and applications. Washington, DC: American Psychological Association.

Voros, F. (2009). The invention of addiction to pornography. Sexologies, 18(4), 243-246. https://doi.org/10.1016 /j.sexol.2009.09.007.

World Health Organisation. (1993). ICD-10 Classification of Mental and Behavioural Disorders: diagnostic criteria for research. Geneva: Switzerland.

World Health Organization (2016). Print versions for the ICD-11 beta draft (mortality and morbidity statistics). Retrieved July 15, 2019, from: https://icd.who.int/browse11/1-m/en\#/http://id.who.int/icd/entity/338347362.

Yalcın-Irmak, A., \& Erdoğan, S. (2015). Validity and reliability of the Turkish version of the Digital Game Addiction Scale. Anatolian Journal of Psychiatry, 16(1), 10-18. https://doi.org/10.5455/apd.170337.

Young, K. S. (1998). Caught in the net: how to recognize the signs of internet addiction and a winning strategy for recovery. New York: John Wiley \& Sons.

Zhang, J.-T., Ma, S.-S., Li, C.-S. R., Liu, L., Xia, C.-C., Lan, J., Wang, L. J., Liu, B., Yao, Y. W., \& Fang, X.-Y. (2016). Craving behavioral intervention for Internet gaming disorder: Remediation of functional connectivity of the ventral striatum. Addiction Biology, 23(1), 337-346. https://doi.org/10.1111/adb.12474.

Publisher's Note Springer Nature remains neutral with regard to jurisdictional claims in published maps and institutional affiliations.

\section{Affiliations}

\section{Mustafa Savci $^{1} \cdot$ Mark D. Griffiths $^{2}$}

\section{Mustafa Savci}

msavci@ firat.edu.tr

1 Department of Guidance and Psychological Counseling, Firat University, Elazig, Turkey

2 International Gaming Research Unit, Psychology Department, Nottingham Trent University, Burton Street, Nottingham NG1 4BU, UK 